Mlađan Popović, Milanka Điporovic-Momčilović, Ivana Gavrilović-Grmuša

University of Belgrade, Faculty of Forestry, Belgrade, Serbia

Review paper

ISSN 0351-9465, E-ISSN 2466-2585

UDC: $674.815: 661.152 .3 ` 13 ` 7$

doi: $10.5937 /$ zasmat2002152P

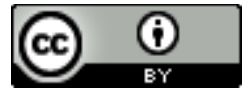

Zastita Materijala $61(2)$

$152-160(2020)$

\title{
New standards and regulations on formaldehyde emission from wood-based composite panels
}

\begin{abstract}
The urea-formaldehyde (UF) adhesive is still most important adhesive system in the production of interior grade particleboards and medium density fibreboards (MDF). However, the furniture and interior fitments, incorporating these products, present one of the sources of formaldehyde emission into the indoor air. The recognition of formaldehyde as a substance that presents the risk for a human health had a strong impact on wood-based panels industry, as it came under constrains by the number of national and international regulations. Hence, this paper presents the overview of standards and regulations that define formaldehyde emission limits for wood-based panels today, and of a special interest for a wood-based panels market in the Republic of Serbia. The paper also gives an overview on a possible methods and procedures for the production of wood-based panels with low or no formaldehyde emission.
\end{abstract}

Keywords: wood-based panels, UF adhesive, formaldehyde, emission standards.

\section{INTRODUCTION}

Wood is a valuable natural resource used in a vast array of applications throughout the human history. It has excellent strength to weight ratio, as well as a unique aesthetic appearance, and possess a number of environmental benefits. Wood products are recyclable, with relatively low $\mathrm{CO}_{2}$ emission during processing and they are sequesters of $\mathrm{CO}_{2}$ during their service life. However, the manufacturing of wood products is not completely free from environmental problems, primarily in the sector of wood-based composite panels, which is heavily dependent on the use of synthetic adhesives. Their use in wood industry began during the third decade of the $X X$ century, with the introduction of phenol-formaldehyde (PF) resins in plywood production [1]. The years following the WWII saw the increased utilization of synthetic adhesives, as well as the development of

\footnotetext{
*Corresponding author: Mlađan Popović

Email: mladjan.popovic@sfb.bg.ac.rs

Paper received: 26. 03. 2020.

Paper accepted: 25. 04. 2020.

Paper is available on the website: www.idk.org.rs/journal
}

new types of wood-based composite products. Today, the most of the adhesives used in the production of particleboards, fibreboards, plywood, laminate floorings etc. are formaldehyde based resins.

Formaldehyde (FA) is the first member in the homologous series of aldehydes. It is the colorless gas with sharp scent that irritates the mucous membrane of the nose and throat. In the form of the $36 \%$ water solution (formalin) it is used for disinfection and other medical purposes. However, much higher quantities of formaldehyde are used in the production of plastic masses and adhesives. It is one of the main crosslinking agents in organic synthetic industry, due to its low cost, high availability and high reactivity. It readily participates in the poly-condensation reactions with the series of other monomers, such as phenol, urea, melamine and others. Depending on the parameters of reaction phases and additives it can be used to produce various synthetic polymer adhesives, lacquers and plastic masses. Today, the production of formaldehyde-based adhesives such as urea-formaldehyde (UF), melamineformaldehyde (MF) and phenol-formaldehyde (PF), consumes more than a half of the total formaldehyde production [2]. 


\section{FORMALDEHYDE EMISSION FROM WOOD-BASED PANELS}

\subsection{Exposure to formaldehyde and health issues}

The human exposure to formaldehyde occurs through inhalation, ingestion or dermal absorption. Increased formaldehyde concentration may lead to various harmful effects on human health. The acute effects mainly relate to sensory irritations of eyes, nose, throat and skin. Exposure to higher concentration or longer exposure time could lead to asthma and other allergic reactions [3]. In adition, the exposure to formaldehyde can cause cancer as a chronical health effect. The International Agency for Research on Cancer (IARC) has classified the formaldehyde into the Group 1, as substance carcinogenic to humans (https://monographs.iarc.fr lagents-classified-by-the-iarc/).

\subsection{The mechanisms of subsequent formaldehyde emission from wood-based panels}

The most used adhesive system in woodbased panels production is the UF adhesive, representing roughly the $80 \%$ [4]. It is the cheapest of the commercial adhesives, yet with some excellent features such as: low curing temperature and high curing rate, good dry strength, and the colourless or white coloured glue line [5-7]. Beside mentioned positive characteristics, the UF adhesive has a certain features in its chemistry that cause two major problems in UF adhesive bonded wood products. One problem is their low resistance against water and moisture, which limits the use of UF adhesive only for interior products, such as the interior grade particleboard and medium density fibreboard (MDF). This is mainly caused by reversible reactions of methylene bridges between nitrogen atoms that leads to degradation of UF adhesive bonds, especially at high temperatures and/or increased humidity. Another problem is the subsequent formaldehyde emission, caused by the same phenomenon related to amino-methylene bridges, but also through hydrolysis of methylene ether bridges and by the residual (unreacted) formaldehyde gas trapped inside the panel structure [8]. The solution to this problem was primarily found in lowering the formaldehyde to urea $(F / U)$ ratio in synthesised resin. During 1970s, the $F / U$ ratio was commonly around 1.6 , while in modern UF adhesive formulations it is usually between 1.02 - 1.08 [9]. It was the success of the UF resin producers to provide the new UF adhesives formulation with relatively low $F / U$ ratio, with limited effect on performance of wood-based panels in terms of physical and mechanical properties.

Level of formaldehyde emission from woodbased panels also depend on the processing conditions, such as the adhesive load and pressing conditions. Those factors, together with the F/U ratio, may be considered as internal factors. There are also external factors that govern the formaldehyde emission in the indoor air, and these are the ambient conditions (temperature, humidity and air exchange rate) and the ratio of total panel area per volume of room [10].

\subsection{Formaldehyde emission standards and regulations}

United States of America was one of the first countries to recognise the problem of formaldehyde emission from wood-based panels and one of the first to implement the emission limits for the products such as plywood and particleboards. During 1980s, the US Housing and Urban Development Agency (HUD) has set the emission limits of $0.30 \mathrm{ppm}$ for particleboards and $0.20 \mathrm{ppm}$ for plywood. Yet, these limits were relatively high by today's standards, probably due to insufficient data on hazardous effects of formaldehyde at that time, or with consideration of the state of manufacturing technology, or due to some other factors [11]. However, one of the important milestones in regulating the formaldehyde emission from wood-based panels came with the Final regulation ATCM 93120, issued by Californian Air Resource Board (CARB), which set more stringent requirements regarding formaldehyde emission, as well as more thorough certification schemes for products. Its implementation came in two phases, with the second one ending in 2012, and effectively setting the lower emission limits for wood-based panels, as given in Table 1 [12]. Moreover, the importance of this act was soon recognised on the federal level and the Environmental Protection Agency (EPA) have adopted the Formaldehyde Standards for Composite Wood Products Act, mostly based on new CARB regulation [13]. Having in mind the huge USA market, this act had a quite important effect on global scale, with more than a dozen of CARB-Approved Third-Party Certifiers working in Europe (https://www.arb.ca.gov/toxics /compwood/listoftpcs.htm).

West Germany, Holland and Denmark were among the first of the European countries to regulate the formaldehyde concentrations in indoor air were. In concern to products standards, at the time of 1980s, the most influential was the West Germany classification of wood-based panels according to formaldehyde potential expressed as the perforator value. Three emission classes were adopted, designated by the letter "E", followed by the number that marks the level of formaldehyde emission. Accordingly, the E1 class designates the panels with the lowest emission, with perforator value (EN 120, ISO 12460-5) less than 10 
$\mathrm{mg} / 100 \mathrm{~g}$.. These panels could be used without limitations. The use of panels that belong to class E2 (10 - $30 \mathrm{mg} / 100 \mathrm{~g})$ required appropriate treatment of both surfaces, while the use of E3 class of panels $(30-40 \mathrm{mg} / 100 \mathrm{~g})$ required the treatment of surfaces and edges [11].

Today, the European Committee for Standardization (CEN) defines the formaldehyde emission limits in technical standards for each type of wood-based panels, such as particleboards (EN 312), OSB (EN 300), fibreboards (EN 622-1) and plywood (EN 636), while the emission limits for wood-based panels used in constructions are implemented in EN 13986. According to these standards' emission limits are divided in E1 and E2 classes of products. The E1 emission class of panels refers to the formaldehyde concentration in air equal or below $0.124 \mathrm{mg} / \mathrm{m}^{3}$, determined by the chamber method (EN 717-1; ISO 12460-1), or approximately $0.1 \mathrm{ppm}$. In a number of European countries the E1 class is the only allowed class of panels.

Table 1. The formaldehyde emission classes for wood-based panels according to EN standards and CARB final regulation order $93120[12,14]$

Tabela 1. Emisione klase ploča na bazi drveta prema EN standardima i CARB regulativi 93120 [12,14]

\begin{tabular}{|c|c|c|c|}
\hline Emission class & $\begin{array}{c}\text { Type of wood-based } \\
\text { panel * }\end{array}$ & Upper emission limit & Test method \\
\hline \multirow{3}{*}{ E1 } & All & $0.124 \mathrm{mg} / \mathrm{m}^{3} \approx 0.10 \mathrm{ppm}$ & Chamber method EN 717-1 [15] \\
\cline { 2 - 3 } & $\mathrm{HP}$ & $0,05 \mathrm{ppm}$ & \multirow{2}{*}{$\begin{array}{c}\text { Large chamber method } \\
\text { ASTM E1333 [16] }\end{array}$} \\
\cline { 2 - 3 } & $\mathrm{PB}$ & $0,09 \mathrm{ppm}$ & \\
\cline { 2 - 3 } & $\mathrm{MDF}$ & $0,11 \mathrm{ppm}$ & $0,13 \mathrm{ppm}$ \\
\hline
\end{tabular}

${ }^{*}$ HP - hardwood plywood; PB - particleboard; MDF - medium density fibreboard

Another important issue in regulating the formaldehyde emission limits is the selection of approved and suitable test method. Different countries and regions might have their own referent and alternative test methods for testing the formaldehyde emission from wood-based panels. As an example, table 2 shows referent, secondary and alternative test methods for formaldehyde, which are used in USA and EU.

Table 2. Test methods for determination of formaldehyde emission from wood-based panels

Tabela 2. Metode za određivanje emisije formaldehida iz ploča na bazi drveta

\begin{tabular}{|l|c|c|c|}
\hline \multirow{2}{*}{ Country/region } & \multicolumn{3}{|c|}{ Test method } \\
\cline { 2 - 4 } & Status & Name & Standard/dessignation \\
\hline \multirow{3}{*}{ European Union } & referent & Test chamber & ISO 12460-1 (EN 717-1) \\
\cline { 2 - 4 } & \multirow{2}{*}{ derived } & Gas Analysis & ISO 12460-3 (EN 717-2) \\
\cline { 2 - 4 } & & Perforator & EN ISO 12460-5 (EN 120) \\
\hline \multirow{4}{*}{ United States } & referent & Test chamber (large) & ASTM E 1333 \\
\cline { 2 - 4 } & secondary & Test chamber (small) & ASTM D 6007 \\
\cline { 2 - 4 } & \multirow{3}{*}{ alternative } & Desiccator method & ISO 12460-3 \\
\cline { 3 - 4 } & & Gas Analysis & ISO 12460-5 \\
\cline { 3 - 4 } & & Perforator & GP TM DMC \\
\cline { 3 - 4 } & & Dynamic Microchamber & JIS A 1460 \\
\cline { 3 - 4 } & & Desiccator method & \\
\cline { 2 - 4 }
\end{tabular}

In Germany, specifically, the new limits are imposed on the formaldehyde emission from woodbased panels by the Chemical Prohibition Order [17]. According to this act, both coated and uncoated wood-based panels must not be placed on the market if the concentration of formaldehyde in the air exceeds 0.1 ppm during testing (E1 class). The furniture made from such panels is also prohibited, except if it complies with the emission limits during the whole-body test. The analytical procedures for determination of formaldehyde emission from wood products are given in the update of this act, which came into effect as of January the 1st, 2020 [18]. The reference procedure included in this act is the test chamber method described in the standard EN 16516:2017 (Construction products - Assessment of release of dangerous substances - Determination of emissions into indoor air). There is also an additional procedure allowed, which is the test 
chamber method described in EN 717-1. However, the results obtained during steady-state emission with this method needs to be multiplied by a factor of 2, as required by the German act. The cause for this correction factor results from differences between the test conditions of these two methods, i.e. EN 16516 requires lower air change and the higher test load than the EN 717-1 [19], as shown in the Table 3. Finally, this act also allows the gas analysis method, described by EN ISO $12460-3$, as a derived procedure. However, this procedure is only suitable for the production control, and requires of manufacturer to determine the productrelated correlation.

Table 3. Comparison of test conditions for two chamber methods EN 16516 and EN 717-1

Tabela 3. Upoređenje uslova ispitivanja između dve razlicite metode komore: EN 16516 i EN 717 1

\begin{tabular}{|l|c|c|}
\hline \multicolumn{1}{|c|}{ Test conditions } & \multicolumn{2}{c|}{ Test methods } \\
\hline & EN 16516 & EN 717-1 \\
\hline Temperature $\left({ }^{\circ} \mathrm{C}\right)$ & $23 \pm 1.0$ & $23 \pm 0.5$ \\
\hline Relative humidity $(\%)$ & 50 & $45 \pm 3$ \\
\hline Loading factor $\left(\mathrm{m}^{2} / \mathrm{m}^{3}\right)$ & 1.8 & $1.0 \pm 0.02$ \\
\hline Air exchange rate $\left(\mathrm{h}^{-1}\right)$ & 0.5 & $1.0 \pm 0.05$ \\
\hline $\begin{array}{l}\text { Unsealed edges to surface } \\
\text { area }\left(\mathrm{m}^{-1}\right)\end{array}$ & 1.5 & 1.5 \\
\hline
\end{tabular}

The Republic of Serbia had the formaldehyde emission limits originally set in Yugoslavian standards for particleboards (JUS D.C5.030:1990). However, the formaldehyde emission was not regulated for other types of wood-based panels, such as plywood or fibreboards. This situation lasted until 2010, when the Serbian Institute for standardization accepted the EN standards concerning for wood-based panels. In 2016 the Serbian Government enacted the Rule on the requirements for particleboards (Pravilnik o zahtevima za ploče iverice, SI. gl. RS, 101/2016), which also includes the formaldehyde emission testing and conformity assessment for both particleboards and OSB panels [14].

\section{RESEARCH ON FORMALDEHYDE EMISSION FROM WOOD-BASED PANELS IN SERBIA}

The increased use of wood-based composite panels in constructions and furniture products have raised the formaldehyde concentrations in the indoor air of residential and public buildings. The significant public response came in 1970s, with consumers, health and environmental organisations in North America and Western Europe demanding the re-evaluation of formaldehyde adverse effects on human health. This led to various regulations concerning formaldehyde, not only in terms of allowed formaldehyde concentration limits in residential and occupational areas, but also regarding allowed emission levels from wood-based panels, specifically for those bonded with UF adhesive. In this way, the formaldehyde emission from these wood products have become the main limiting factor in their successful marketing and sales. At the beginning of 1980s, particleboards were already being produced in Yugoslavia, and the few existing companies sought the opportunity for export on Western European market. Hence, it was necessary to adopt the emission standards and to fulfil the requirements of the importing countries. It was possible to produce $\mathrm{E} 1$ class of panels at that time, but it was far more expensive. The only particleboard factory in Serbia was capable of producing the E2 class of panels, yet it was more problematic to achieve E1 class. Also, the production of E1 class of UF adhesives was still in its trial phase. On the other hand, the selection of appropriate test method yet needed to unify the views of interesting parties, such as health and environmental organisations, adhesive and panel producers, as well the regulatory institutions in this field. The questions were also addressed to what each method determines, because the sources and the manifestations of formaldehyde are various [20]. Although, the emission test chamber was already recognized worldwide as the most valid referent method, it is expensive and requires an extensive test time, from several days to few weeks. This was the opposite of what the industrial practice needs, and that is a fast control method. For these reasons, many European countries have adopted the perforator method for their factory control testing. It is far less expensive than the chamber methods and can produce the results in a relatively short time of a few hours. However, the perforator method is essentially an extraction method that measures the formaldehyde content in wood-based panels, and not the actual emission of formaldehyde from the panels. There is also a question of its validity at the emission levels below $0.1 \mathrm{ppm}$ [21]. Roffael et al. (2010) studied the correlation between the $1 \mathrm{~m}^{3}$ chamber method and the perforator method, by using wood-based panels of low formaldehyde emission. They did point at the problem with the existing formula, which is used in this method to correct measured values according to the required level of moisture content of the board $(6.5 \%)$ [22].

Faculty of Forestry in Belgrade was also involved in finding solutions to the problem of formaldehyde emission from wood-based panels. Its research team have contributed in studying the sources and mechanisms of formaldehyde liberation, and the methods of its reduction. The 
research activities started in mid 1980s to analyse and compare the methods for determination of free formaldehyde, in order to help with standardization process on national and international level, since fully agreement was not yet achieved. Initially, the following considerations were taken into account: 1) perforator method is based on a forced extraction and the formaldehyde potential represented both free formaldehyde and a certain amount of weakly? bonded formaldehyde, 2) desiccator and WKI diffusion methods do not reproduce real processing conditions (high humidity increases formaldehyde emission) for determination of formaldehyde released from panel into surrounding air, 3) these methods were the most used for classification of wood-based panels in Europe, at that time [23]. The study involved the testing of free formaldehyde and the comparison of results between the following methods: perforator method, WKI-24 and WKI-4. The perforator method involves more complex testing procedure and requires skills operators. However, it was less reliable for the low levels of free formaldehyde in the panels, E1 and lower E2 class. Yet, it was found suitable for testing the panels of E3 and upper E2 class. The WKI-24 is a simpler method, but with the test duration of $24 \mathrm{~h}$ it is not suitable for
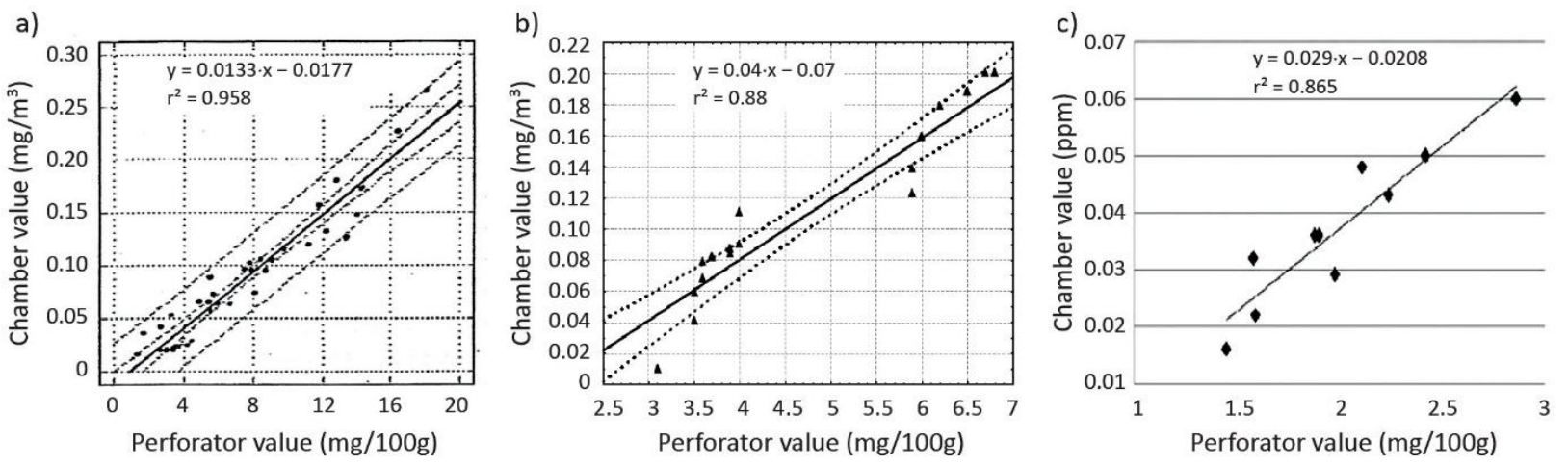

prompt reactions during production process. However, this method more resembles the real application conditions and it is the least destructive. Hence, it was proposed as relatively cheap and effective method for testing the formaldehyde emission from wood-based panels. This study also found the irregularities between the extracted and emitted amounts of free formaldehyde during first 21 days after production. After that period, the uniformity of the results was restored. However, this findings emphasised the caution when determining the classes of fresh produced panels.

The above research was continued with another one, which was aimed at lowering the emission of free formaldehyde from plywood and particleboard, while preserving the physical and mechanical properties of panels. This research also involved three different test methods for determination of formaldehyde potential and emissions: perforator method, WKI and small chamber method. As an example, the correlation of the results obtained by perforator method and the test chamber method, in the scope of this research, are shown in the Fig. 1 [24], and also in comparison to correlations from other sources $[21,25]$.

Figure 1. The correlations between perforator value and the test chamber formaldehyde emission value, as determined by different authors: a) Crnogorac (1992) [24]; b) Salem et al. (2012) [21] and c) Johnsson et al. (2014) [25]

Slika 1. Korelacije između perforator vrednosti i vrednosti komora za emisiju formaldehida, određen od strane različitih autora: a) Crnogorac (1992) [24]; b) Salem et al. (2012) [21] and

c) Johnsson et al. (2014) [25]

Three methods for the reduction of formaldehyde were analysed: 1) the application of UF adhesive with low formaldehyde content, 2) addition of scavenger into UF adhesive (pretreatment) and 3) addition of scavenger on the produced panels (post-treatment). In addition, the production parameters were also studied, namely, the addition of adhesive and the hot press temperature (Fig. 2). This study showed several interesting results. Firstly, it is easier to retain the mechanical properties with plywood then for the particleboard, while achieving the lower formaldehyde emission. With both types of panels, the use of UF adhesive with low formaldehyde content was much efficient than the use of UF adhesive with scavengers. Finally, the lower amount of adhesive with increased pressing temperature resulted in decrease of formaldehyde emission for both plywood and particleboard [24]. 


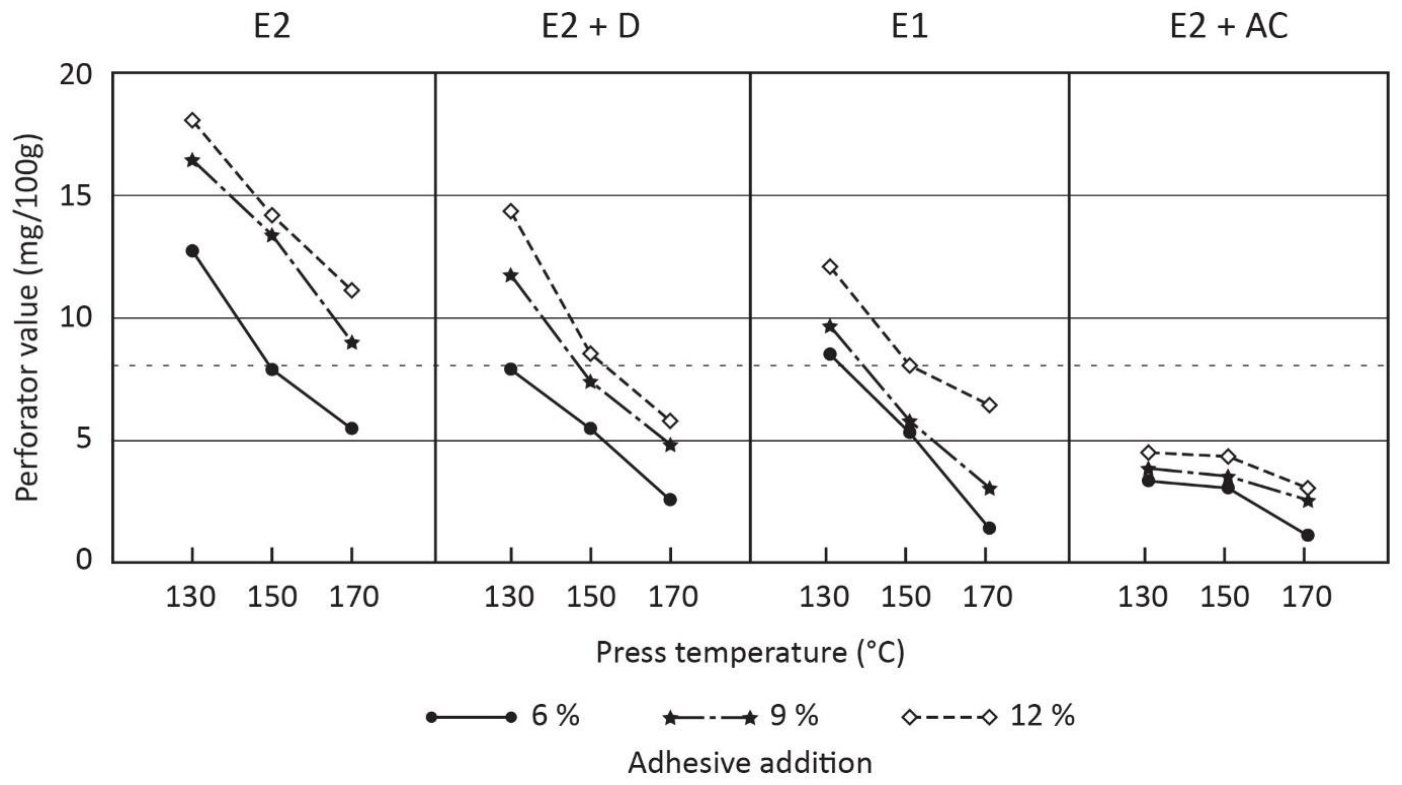

Figure 2. The influence of press temperature and adhesive addition on the formaldehyde potential of particleboards bonded with different UF adhesive types (E1 and E2 class), with addition of urea-based scavanger (D - Dusad), and post-treated with ammonium carbamate (AC) [24]

Slika 2. Uticaj temperature presovanja i dodatka adheziva na sadržaj formaldehida u pločama ivericama vezanim različitim tipovima UF adheziva (E1 i E2 klasa), sa dodatkom hvatača (D - Dusad), i nakon posttretmana sa amonijum karbamatom (AC) [24]

\section{WOOD-BASED PANELS WITH LOW OR WITHOUT FORMALDEHYDE EMISSION}

The possibility to produce emission free or at least significantly low formaldehyde emission wood-based panels, have been a matter of numerous studies that could be grouped into several categories according to their main idea or applied methodology. Hence, the reduction or elimination of formaldehyde emission from woodbased panels could be achieved through the following solutions or strategies:

Lowering the formaldehyde to urea molar ratio. The attempts to reduce the formaldehyde emission from wood-based panels was mainly achieved by optimizing the UF adhesive synthesis and formulations. This resulted in modern UF adhesives with low F/U ratio, as much as 1.02. However, further lowering of $F / U$ ratio would diminish the effects of formaldehyde as the main reactant in condensation and crosslinking reactions of the UF adhesive [9]. Hence, the emission from UF adhesive bonded wood products still exists, and although relatively low, it may present a problem in some application scenarios.

Application of scavengers for formaldehyde. The use of scavengers is also an old idea and thoroughly utilized method in lowering the formaldehyde emission from wood-based panels, bonded with UF adhesives. Formaldehyde scavengers can be used as a pre-treatment procedure when they can be mixed with UF adhesive or impregnating the wood particles prior to hot press operation. They can be also applied through a post-treatment procedure, by spraying over the panel surfaces. Urea itself may act as a scavenger, when subsequently added in UF adhesive. Ammonia and ammonia salts present yet another successful scavenger. However, the use ammonia as a scavenger is decreasing due to health issues [10]. Similarly, with the approach of changing the $\mathrm{F} / \mathrm{U}$ moral ratio, the use of scavengers with UF adhesives also has a barrier, i.e. the limit of maximal addition range at which the physical and mechanical properties of produced panels are deteriorating.

Substitution of UF adhesive with other synthetic adhesives. The use of other types of formaldehyde-based adhesives, such as PF adhesives and melamine modified UF adhesives (UMF), already has a long tradition in wood-based panels production. However, these types of adhesives are used only for the boards with increased water resistance (for use in conditions with higher humidity and in occasional contact with condensed water). They are more expensive than 
pure UF adhesive, and PF adhesive also requires higher curing temperatures and longer curing time. In addition, both adhesives are not completely free of formaldehyde emission, especially concerning MUF adhesive [7]. A solution for a formaldehyde free presents a polymeric diphenylmethanediisocyanate (pMDI). It is characterised with high reaction rates, high bond strength and excellent water resistance [9]. However, they are much more expensive than UF adhesives. In addition, a special care is needed with their application, as they have the affinity to stick with metal elements in hot press [26].

Substitution of UF adhesive with bio-based adhesives. The use of natural, bio-based adhesives is still far from large industrial scale applications in wood-based panels production. The interesting propositions, however, lies in partial or full substitution of UF adhesives with tannin- or lignin-based adhesives, or with soy protein adhesives. Although, most of these solutions are extensively studied, much of the improvements are still needed in order to make bio-based adhesives economically feasible or efficient enough in real processing conditions, as well as to meet the performance of synthetic adhesives in terms of water resistance and bonding strength [27].

Using alternative reactants instead of formaldehyde. Having in mind that the urea is non-toxic substance, while the formaldehyde is, there was a reasonable idea to look for another reactant for urea. The transformation of UF adhesive into green urea-based adhesive can be approached through full or partial replacement of formaldehyde with another aldehyde. The most promising solution lies in the use of glyoxal. It is a non-volatile and non-toxic aldehyde, colourless and with relatively low price. However, it is less reactive than the formaldehyde [28].

\section{CONCLUSIONS}

The secondary, or subsequent emission of formaldehyde from wood-based composite panels refers to the emission that occurs from panels during the service life. During 1970s, it was found to be one of the major contributors of formaldehyde concentration in the indoor air of a residential homes or public buildings.

Amongst the wood-based panels, the ones bonded with UF adhesive have the highest levels of formaldehyde emission. The first formaldehyde emission limits from such wood products were set through the regulations and standards in North America and some countries of Western Europe during late 1970 s and early 1980s.
Since the 1980s, the problem with formaldehyde emission from wood-based panels was recognized on a global scale. More and more countries were adopting their emission limits and test methods, mostly according to the regulations and standards in leading world economies, such as USA or West Germany.

Today, the producers of wood-based panels face more detailed and stringent certification procedures, and more stringent limits in terms of formaldehyde emission from wood products in general. As the most influential regulations one can address to the CARB final rule and its phase 2 formaldehyde emission limits, as well as to the series of EU standards.

In 1980s, the Yugoslav standards also set the Formaldehyde emission limits, but only for particleboards. The requirements for particleboards, including the formaldehyde emission from domestically produced panels, were also regulated by the National Order from 1983. The Republic of Serbia effectively replaced this Order in 2016, by new regulatory act for particleboards, which also included the OSB panels.

There are several routs in producing the UF bonded wood-based panels with low or no emission of formaldehyde. The lowering of $\mathrm{F} / \mathrm{U}$ molar ratio of UF adhesive or the use of scavengers were both successful solutions in producing the panels that comply with formaldehyde emission standards. However, both seems to have reached a final compromise between the low formaldehyde emission and the physical and mechanical properties of the board.

Production of interior class of panels that will have no formaldehyde emission requires more daring solutions. Possible ones are the replacement of formaldehyde with another reactant for urea, or the use of non-formaldehyde emitting adhesive, preferably the bio-based adhesives. However, the combination of urea and formaldehyde seems to endure in the most crucial aspects of adhesive application on industrial scale, either in terms of price or performance in processing conditions or through the physical and mechanical characteristics of produced panels.

\section{Acknowledgements}

This paper was realized as a part of the project "Establishment of Wood Plantations Intended for Afforestation of Serbia" (TP 31041) financed by the Ministry of Education and Science of the Republic of Serbia within the framework of integrated and interdisciplinary research for the period 2011-2014. 


\section{REFERENCES}

[1] C.R.Frihart (2015) Wood Adhesives: Past, Present, and Future. Forest Products Journal, 65(1,2), 4-8.

[2] L.Axelsen (2015) Outlook for Formaldehyde and Impact on Methanol Demand. 33rd Annual IHS Chemical World Methanol Conference, 11-12. November 2015, Munich, Germany.

[3] D.A.Kaden, C.Mandin, G.D.Nielsen, P.Wolkoff (2010) Formaldehyde - Chapter 3 in: WHO Guidelines for Indoor Air Quality: Selected Pollutants, World Health Organization.

[4] I.Katsampas (2006) New Trends in Wood Adhesive Technology, 6th Panhellenic Polymer Conference, 5 novembar 2006, Patras, Greece.

[5] M.Irle, M.C.Barbu (2010) Wood-Based Panel Technology. In: H.Thoemen, M.Irle, M.Sernek (eds) Wood-Based Panels - An Introduction for Specialists, Brunel University Press, p. 1-94.

[6] D.Sandberg (2016) Additives in Wood Products Today and Future Development. In: A.Kutnar and S.S.Muthu (eds) Environmental Impacts of Traditional and Innovative Forest-based Bioproducts, p. 105-172.

[7] V.Hemmila, S.Adamopoulos, O.Karlsson, A.Kumar (2017) Development of sustainable bio-adhesives for engineered wood panels - A Review. RSC Advances, 7, 38604-38630.

[8] M.Dunky (1998) Urea-formaldehyde (UF) adhesive resins for wood. International Journal of Adhesion \& Adhesives, 18, 95-107.

[9] M.Dunky (2003) Adhesives in the Wood Industry. In: Pizzi, A. and Mittal, K.L. (eds) Handbook of Adhesive Technology - Second Edition, Revised and Expanded. Marcel Dekker, Inc., New York, Basel.

[10] A.Aguilera, J.P.Davim (2017) Wood Composites Materials, Manufacturing and Engineering, Walter de Gruyter $\mathrm{GmbH}$, Berlin/Boston.

[11] T.Godish (1989) Indoor Air Pollution Control. Lewis Publishers, CRC Press Inc.

[12] CARB (2008) Airborne Toxic Control Measure to Reduce Formaldehyde Emissions from Composite Wood Products - Final Regulation Order 93120. California Environmental Protection Agency Air Resources Board https://www.arb.ca.gov/regact/2007/compwood07/fr o-final.pdf

[13] EPA (2016). Formaldehyde Emission Standards for Composite Wood Products. Environmental Protection Agency, https://www.regulations.gov /document? D=EPA-HQ-OPPT-2016-0461-0001

[14] M.Điporović-Momčilović, M.Popović, I.GavrilovićGrmuša, J.Popović, A.H.Mohamad (2018) Formaldehyde emission standards for wood-based panels and testing capacities in Serbia. In proceedings of 11th International Scientific Conference WoodEMA 2018: Increasing the Use of Wood in the Global Bioeconomy.

[15] EN 717-1 (2004) Wood-based panels - Determination of formaldehyde release - Part 1: Formaldehyde emission by the chamber method.
[16] ASTM E1333 (2014) Standard Test Method For Determining Formaldehyde Concentrations In Air And Emission Rates From Wood Products Using A Large Chamber.

[17] ChemVerbotsV (2017) Verordnung über Verbote und Beschränkungen des Inverkehrbringens und über die Abgabe bestimmter Stoffe, Gemische und Erzeugnisse nach dem Chemikaliengesetz (Chemikalien-Verbotsverordnung).

[18] BAnz AT 26.11.2018 B2 (2018) Bekanntmachung analytischer Verfahren für Probenahmen und Untersuchungen für die in Anlage 1 der Chemikalien-Verbotsverordnung genannten Stoffe und Stoffgruppen.

[19] A.Cecchini (2019) Export Germany, new formaldehyde emission limits for wood-based products. http://www.cosmob.it/en/2019/10/03/exportgermania-emissioni-formaldeide/

[20] G.Myers (1983) Formaldehyde Emissin From Particleboard and Plywood Paneling: Measurement, Mechanism and Product Standards, Forest Product Journal, 33(5), 27-37.

[21] M.Z.M.Salem, M.Bohm, J.Srba, J.Berankova (2012) Evaluation of formaldehyde emission from different types of wood-based panels and flooring materials using different standard test methods. Building and Environment, 49, 86-96.

[22] E.Roffael, B.Johnsson, B.Engstrom (2010) On the measurement of formaldehyde release from lowemission wood-based panels using the perforator method. Wood, Science and Technology, 44, 369377.

[23] O.Crnogorac (1987) Uporedno određivanje slobodnog formaldehida u ivericama različite starosti, Magistarski rad, Univerzitet u Beogradu-Šumarski fakultet, p. 110.

[24] O.Crnogorac (1992) Istraživanje mogućnosti smanjenja emisije slobodnog formaldehida iz drvnih ploča, doktorska disertacija, Univerzitet u BeograduŠumarski fakultet, p. 132.

[25] B.Johnsson, E.Roffael, C.Behn (2014) Assessment of lowering formaldehyde release of particleboards using urea as a scavenger by chamber, perforator and flask method, International Wood Products Journal, 5(1), 50-54.

[26] G.I.Mantanis, E.T.Athanassiadou, M.C.Barbu, K.Wijnendaele (2017) Adhesive systems used in the European particleboard, MDF and OSB industries. Wood Material Science \& Engineering, p. 1-12, https://doi.org/10.1080/17480272.2017.1396622

[27] A.Pizzi (2017) Urea-glyoxal and Melamine-glyoxal adhesives for wood panels and other applications for the total elimination of formaldehyde, Proceedings of the International Conference on Wood Adhesives, Oct 25-27, Atlanta, GA.

[28] F.Ferdosian, Z.Pan, G.Gao, B.Zhao (2017) BioBased Adhesives and Evaluation for Wood Composites Application. Polymers, 9(2), 70-79. 


\section{IZVOD}

\section{SAVREMENI STANDARDI I PROPISI O EMISIJI FORMALDEHIDA IZ KOMPOZITNIH PLOČA OD DRVETA}

Urea-formaldehidni (UF) adheziv je još uvek jedan od najvažnijih adhezivnih sistema u proizvodnji ploča iverica i ploča vlaknatica srednje gustine (MDF). Međutim, nameštaj i elementi enterijera koji sadrže ove proizvode predstavljaju jedan od izvora emisije formaldehida u unutrašnjem prostoru. Prepoznavanje formaldehida kao supstance štetne po zdravlje čoveka imalo je snažan uticaj na sektor proizvodnje ploča na bazi drveta, pošto su se ovi proizvodi našli pod ograničenjima od strane brojnih nacionalnih i međunarodnih regulativa. Shodno tome, ovaj rad predstavlja pregled standarda i regulativa koji danas definišu emisione granice za ploče na bazi drveta, a od značaja su za tržište ovih ploča u Republici Srbiji. Ovde se, takođe, daje i kratak pregled metoda $i$ procedura u proizvodnji ploča na bazi drveta sa veoma niskom ili bez emisije formaldehida.

Ključne reči: ploče na bazi drveta, UF adheziv, formaldehid, standardi emisije

Pregledni rad

Rad primljen: 26. 03. 2020.

Rad prihvaćen: 25. 04. 2020.

Rad je dostupan na sajtu: www.idk.org.rs/casopis

(c) 2020 Authors. Published by Engineering Society for Corrosion. This article is an open access article distributed under the terms and conditions of the Creative Commons Attribution 4.0 International license (https://creativecommons.org/licenses/by/4.0/) 